\title{
İslamiyet Öncesi Eski Türk İnanışları veya Mitolojisi ile Antik Dönem (Yunan veya Roma) Mitolojisinin Karşııkıı Olarak Değerlendirilmesi
}

\section{Mutual Evaluation of Ancient Turkish Beliefs or Mythology before Islam and the Ancient Period (Greek or Roman) Mythology}

Derya Uzun Aydın ${ }^{a^{*}}$

${ }^{\mathrm{a}}$ Dr. Öğr. Üyesi, Batman Üniversitesi, Fen Edebiyat Fakültesi Sanat Tarihi Bölümü, Batı Raman Batman/Türkiye ORCID: 0000-0001-8063-2144

\section{MAKALE BILLGİSI}

Makale Geçmişi:

Başvuru tarihi 01 Şubat 2018

Düzeltme tarihi 01 Mayıs 2019

Kabul Tarihi 06 Mayıs 2019

\section{Anahtar Kelimeler:}

Mitoloji

Orta Asya

Eski Türkler

Antik Dönem

\section{A R T I C L E I N F O}

\section{Article history:}

Received 01 February 2019

Received in revised form 01 May 2019

Accepted 06 May 2019

\section{Keywords:}

Mythology

Middle Asia

Old Turks

Antiquity

\section{ÖZ}

Mitoloji, "Efsaneler Bilimi” olarak da adlandırılabilir. Mitoloji temasının Avrupa ve kökeninin dayandığ1 Antik Yunan veya Roma için ne kadar önemli olduğu tartışılmaz bir gerçektir. Bu bağlamda, Eski Türklerde mitolojik tema öykülerinin de ne kadar değerli olduğu gerçeği ortaya çıkacaktır. Türk mitolojisinde, ata kültü, tanrı inancı özellikle Şamanizm veya Budizm, balballar, anıtlar, göçebe yaşam kültü ve elbette hayvan üslubu Türk sanatı ve mitolojisinde akla ilk gelen konular olmaktadır. Avrupa Mitolojisine kaynaklık eden Yunan veya Roma mitolojisi de evren ve dünyanın başlangıcı, insanın var oluşu, doğada var olan olgular ve Olympos'lu büyükler yani Tanrı, Tanrıça, Yarı Tanrılar veya mitolojik-efsanevi yaratıklardan oluşan zengin mitolojisi ile dikkat çekmektedir. Olaylar örgüsünde doğma, yaşam, evren, doğa gibi kült inanışların varlığı görülecektir.

A B S T R A C T

Mythology can also be called as "Science of Legends". The importance of the theme of mythology for ancient Greek and Roman which was based on Europe and its origin is an is disputable truth. In this context, the fact that how important were the mythological theme stories Old Turks will be relieved. In Turkish mythology, ancestor cult, god faith especially Shamanism or Buddhism, "balbals", nomadic life cult, and of course animal style are the first topics that come to mind concerning Turkish art and mythology. The Greek or Roman mythology, which originated in the European mythology, attracts attention with its mythology, which consists of the universe and the beginning of the world, the existence of man, the phenomena that exist in nature and the great people of Olympos, God, Goddess, Half Gods or mythological-mythical creatures. The existence of cult beliefs such as birth, life, universe, nature will be seen in the weave of events.

\section{Giriș}

Türkler ve mitoloji teması incelenmeye çalışılan farklı iki temadır. Her iki tema aslında, kitaplar dolusu konuları içermektedir. Bir de Antik dönem mitolojisi vardır ki, Avrupa mitolojisine kaynaklık ederek günümüz sanatına kadar değerlendirilebilecek bir tema olarak varlığını sürdürür.
Mitoloji ve Türk kelimeleri, bir araya çok sık gelmeyen kavramlardır. Ya da öyle olduğu düşünülebilir. Ancak ayrıntılarla ele alındığında, Türk mitolojisinin de ne kadar değerli ve geniş kapsamlı olduğu gözlenecektir. Bu konuyu sanat bazında incelerken, karşımıza ilk etaplarda özellikle balballar, ya da hayvan üslubu örnekleri gelmiştir. Ancak Türk mitolojisi ve sanatında değerlendirmeye alınabilecek, yaratılış ve türeyiş efsaneleri, tanrılar, evren ve

\footnotetext{
* Sorumlu yazar/Corresponding author

e-posta: calukya@gmail.com
} 
kozmografyası ve tabii ki hayvanlar gibi başlıca temaların olduğu gözlemlenmiş ve çalışma bu doğrultuda oluşturulmaya çalışılmıştır.

Eski Türkler denilince, çalışmada öncelikle Hun, Göktürk ve Uygurlar değerlendirilmeye çalışılmıştır. Kimi araştırıcıya göre Türk sayılan Sümerler de konuya dahil edilmiştir.

Dikkat edildiğinde Orta Asya Türk mitoloji teması; kimi zaman dini inanışlar kimi zaman tanrılar, çoğunluk hayvan motifleri ki özellikle yine bir ruh veya tanrı simgesi yada güç simgesi olarak karşımıza çıkmaktadır.

Peki anlatılmaya çalışılan bu mitoloji nedir? B. Mutlu, "mitoloji" kelimesinin karşılığ $\breve{1}_{1}$ olarak "Bir dinle ilgili efsaneler ya da anlamını, kökenini ve gelişmesini belirtmek için çeşitli efsanelerin karşılaştırmalı incelemesi. Efsaneler bilimi de denilebilir" demektedir. (Mutlu, 1997:1273-1276). Ayrıca, eski çağ ya da ilkel toplumlarda doğa olayları, insan yaşantısı, evren ve yaratılış, gerçeküstü kişiler, tanrılar, efsanevi yaratıklar, savaşlar ve kahramanlar kimi konular arasinda yer almaktadır.

Dünyanın dört bir tarafına dağılmış olan Türkler, göçebe yaşam tarzı ile birçok kültür ve medeniyet tanımış ve bunlarla büyük oranda etkileşime geçmişlerdir. Bu durum Türklerin diğer milletlerle olan kültür alışverişini de güçlendirmiş ve belki de ortak mitoslar oluşturmalarına vesile olmuştur. (Tansü \&Güvenç, 2015:203-218).

\section{Antik Mitolojide Yaratılış}

Antik mitolojide yaratılış öyküsü oldukça detaylı olarak anlatılmaktadır. Başlangıçta Khaos yani sonsuz boşluk vardır. Boşluktan Gaia yani toprak ana doğmuştur. Sonra ölüler ülkesinin en derin yeri Tartaros, sonra Aşk yani Eros, sonra yer altı karanlığı Erobos ile yeryüzü karanlığı Nyks yani gece doğmuştur. Erobos ve Nyks birleşip Gök'ü yani Aither'i ve Gün yani Hemera'yı meydana getirirler. Toprak ana Gaia da, Uranus (Gök), Deniz (Pontos) ve dağları yaratır (Cömert, 1999:17 ; Yücel, 2016:25).

Tanrısal uzuvların atıldığı deniz köpükler çıkarır ve Aphrodite doğar. Annesi Gaia ile birleşen Pontos'dan deniz tanrı veya tanrıçaları türer. Perseus tarafından başı kesilen Medusa'nın kanından kanatlı at Pegasos doğar. Hades'in köpeği Kerberos da bu sıralar türemiştir. Titanların çocuklarının evlenmesinden Helios yani güneş ve Selene yani ay ve eos yani şafak meydana gelmiştir. (Cömert, 1999:1718). (Titanlar ilk Tanrılar soyu olup, Uranos ve Gaianın oğullarıdır: Necatigil, 2011:151).

Yunanlılardan Roma'ya geçen tanrı veya kahramanlar, önceki çağların olayları üzerine sanatla öne çıkmaktadır. (Yücel, 2016:14).

Titan İapetos'un, Okeanos kıı Klymene'den dört erkek çocuğu olmuş, bunlar; Atlas, Prometheus, Epimetheus ve Menoithios'tur.

İnsanın Prometheus tarafindan, maddeden yaratıldığı, daha doğrusu 'yapıldığı' efsanesi, geç bir dönemde, İ.Ö. IV. yüzyılda ortaya çıkmıştır. Bu efsaneye göre Prometheus, suya ya da gözyaşlarına kil karıştırarak, ölümlü ilk varlığın bedenine biçim vermiş, sonra çamurdan yapılmış bu bedene yaşam soluğunu üflemiştir. Bir başka söylenceye göre Prometheus, ilk insanın yalnızca yapıcısıdır, onu yalnızca biçimlendiren kişidir. İlk insana hayatı, ruhu, Athena vermiştir. Ayrıca yine efsaneye göre; insanlara ceza olsun diyerek ilk kadın gönderilmiş, bu güzel ve belalı yaratığa 'tanrılar armağanı' anlamına gelen "Pandora" denilmiştir.

Yaratılış öyküsünde birbirini izleyen beş insan soyu anlatılmaktadır. Olympos'ta oturan ölümsüzlerin yarattığı ilk soy olan altın soy, Kronos zamanında yaşamıştır. Tanrılar gibi yaşamıştır insanlar. Yaşlılık nedir bilmemişlerdir. Dünyanın bütün nimetleri onlara aittir. Sayısız nimetler ortasında yaşayıp gitmişlerdir. Dünyada da, hep ilkbahar vardır. Bitkiler kendiliğinden büyümüştür. $\mathrm{Bu}$ ilk insanlar ölüp topră̆a karışınca, toprağı ve insanları koruyan iyi birer cin olmuşlardır.

Zeus, Kronos'u alt edip Tartaros'a atınca, tanrılar gümüş soyunu yaratmıştır. Bunlar, yüz yıl çocuk olarak kalmışlardır. Büyüyüp ergin çağa gelince de hayatları pek uzun sürmez. Ölümsüzleri saymamışlar ve onları cezalandırmak için ilkbaharın süresini kısaltmışlardır ve yılı dört mevsime bölmüşlerdir. Böylece insan, soğuktan ve sicaktan korunabilmek için mağara ve kulübelere sığınmıştır. Karnını doyurabilmek için de, toprağı işlemek zorunda kalmıştır. Zeus bu kuşağı toprağa gömer. Gümüş soylular da böylelikle, yeraltı cinleri olurlar. Bir üçüncü kuşak yaratır Zeus; Tunç soyu. Tunçtan silahları, tunçtan evleri olur. Tunçla toprağı kazırlar. $\mathrm{Bu}$ tunç soylularının işleri güçleri saldırmak, öldürmektir. Hep birbirleriyle savaşır, birbirlerini öldürürler. Sonunda, Hades'in ürpertili karanlıklarında yok olup giderler. (Cömert, 1999:22)

Yarı tanrı kahramanlar ise dördüncü soydur. Büyük işler becererek, insanlığın adını yücelten bu kahramanlar da, çetin savaşlar sonucu yok olup giderler. Beşinci soy hepsinden beter olur. Demir çağıdır bu. Bu çağda, acılar ve felaketler insanların yakasını hiç bırakmaz.

Tufan, tunç çağında, ya da demir çağında olmuştur. Zeus'un, günahkar insanları bir tufanla yok etmek istediğini Prometheus, oğlu Deukalion'a bildirir. Deukalion, bunun üzerine bir tekne yapar, bütün gerekenleri de yanına alarak, karısıyla birlikte bu tekneye sığınır. Hemen bütün Yunanistan sular altında kalır. Teknesi dokuz gün ve dokuz gece sular üzerinde yüzdükten sonra, Parnassos dağının tepesinde durur. Burada Deukalion, kaçanların koruyucusu Zeus'a kurban keser. Tanrılar kralı, elçisi Hermes'i Deukalion'a gönderir, ondan ne istediğini sordurtur. Deukalion, yok olan insan soyunun yeniden yaratılmasını diler. Dileği kabul eden Zeus, karı kocaya "Ana'nın kemiklerini arkalarına atmalarını" söyler. Ovidius'a göre Deukalion ve Pyrrha, dünyada yapayalnız kalırlar. Deukalion dünyada kalan tek erkektir, Pyrrha ise dünyada kalan tek kadındır. Bu dünyada korkarlar ve Dua için Themis tapınağına giderler. Themis bilicisi şu karşılığı verir: "Başınızı örtün, giysinizin bağını çözün ve Büyük Ana'nın kemiklerini arkanıza atın!" Deukalion bu sözlerin anlamını çözmeyi başarır. Büyük Ana dediği, Toprak Ana olmalıdır, kemikler de taş. Bunun üzerine yerden taşları alıp, arkalarına atmaya başlarlar. Onlar attıkça, taşlar taş olmaktan çıkıp insan biçimini alır. Deukalion'un attığı taşlar erkek, Pyrrha'nın attıkları ise kadın olurlar. (Cömert, 1999:23).

\section{Eski Türklerde Doğma, Yaşam ve Evrene Bakış}

Yaygın bir inanışa göre, Eski Türklerin hayvandan türediğine inanılmaktadır. Bu hayvanın da özellikle bir kurt olduğu 
düşünülmektedir. (Çoruhlu, 2011b:122). Göktürklerin Hunların soyundan geldiği ve hatta onların bir kolu olduğu düşünülmektedir. (Deveci, 2013:795-810).

Kaynaklardan edinilen bilgi ve hikayeye göre, Göktürk Devleti Lin denilen bir devlet tarafindan yenilgiye uğrar. Bu savaş neticesinde yalnızca kolu ve bacağı kesilmiş bir çocuk geride kalmıştır. Bu çocuğu bulan bir dişi kurt, onu alır besler ve hatta onunla birlikte olur. Bu ikisinden doğma çocukların da, Göktürk soyunu devam ettirdiği düşünülmektedir. Bu bağlamda Göktürklerin Burgut Abidesi (R.1), bu efsaneyi anlatmakta ve kurttan süt emen bir çocuğu göstermektedir. Dişi kurttan doğan kız çocuğunun da Türklerin kurucusu olduğu ve bu kızın da olağanüstü yeteneklere veya sihre sahip olduğuna inanılmaktadır. Bazen de dişi kurt bir Türk kızı olarak gösterilmektedir. (Çoruhlu, 2011b:123-124 ; Deveci, 2013:795-810).

R. 1: Burgut Yazıtı. Üst kısımda Kurttan Süt Emen bir Çocuk Gözlenmektedir

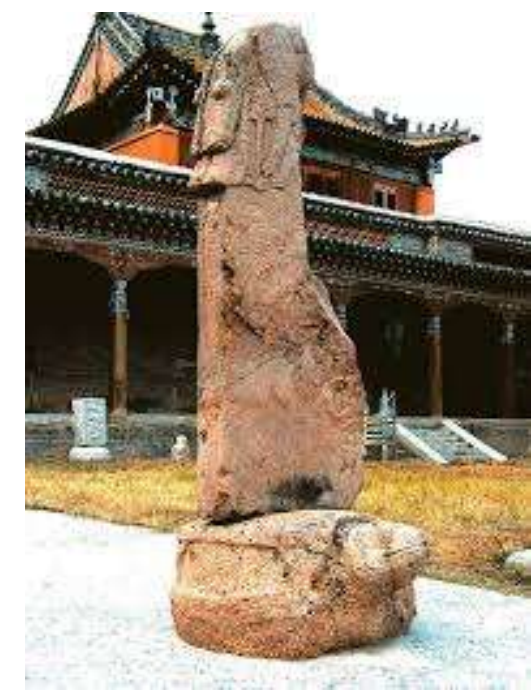

(Çoruhlu, 2011a:189)

İlginç bir biçimde Romalılarda da, bir dişi kurdun çocukları emzirdiği sahnelere tanıklık edilmektedir. (R.2). Olay şöyle gelişmiştir; Latium bölgesinde Kral Numitor, erkek kardeşi tarafından devrilmiştir. Kralın kızının yeni varisler doğurmaması için bakire kalması sağlanmaya çalışılmış ancak bir gün bu kı, Mars'1n tecavüzüne uğrayarak "Romulus ve Remus" isimli ikiz çocukları dünyaya getirmiştir. Bu çocuklar ölmesin diye Tiber nehri kıyısına terk edilirler. İşte bu anda bir dişi kurt onları bulup, emzirmeye başlar. Sonra da bir çoban bu çocukları yanına alır. Çocuklar büyüyüp de, kraliyet soyundan geldiklerini öğrenince, Numitor'un tekrar başa geçmesini sağlarlar ve böylece yeni kurulan kente isim olarak "Roma" ad1 verilir.(MÖ.4.yy.lar). (Ergüven, 2012:115).
R.2: Romalılar'da Kurttan Süt Emen Çocuklar
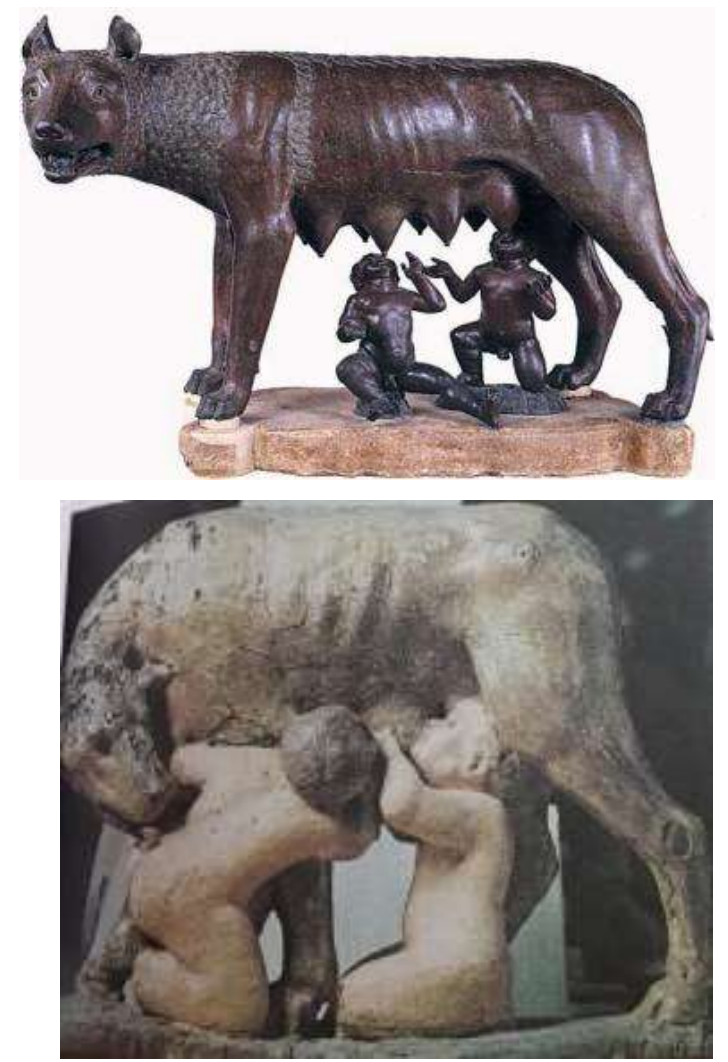

(Ergüven, 2012:115; Jung, 2009).

Oğuz Türklerinde ise Oğuz boyları ve Oğuz Kaan'ın gök ve yerin kızı ile evlendiği anlatılır. Ve bu şekilde soy devam eder. Ayrıca Türklerin ăgaçtan türediğine inananlar da söz konusudur. (Çoruhlu, 2011b:125-126,130).

Eski Türk inanışına göre, Türkler dünyayı kimi zaman bir kare, kimi zaman da bir dikdörtgen şeklinde tasarliyorlar ve bunun içerisinde yer alan dairenin gökyüzünü simgelediğini düşünüyorlard1. Dairenin merkezinde de bir kutsal dağ veya kutsal bir ağaç durduğuna inanmaktaydılar. Bunlar da çeşitli katlara ayrılmış ve yer ile gökyüzünü birleştirmiştir. Yeryüzü dört yöne ayrılmış ayrıca yeraltının da cehennem olduğu düşünülmüştür. (Çoruhlu, 2011b:97 ).

Doğum ve ölüm okyanusunun adı Samsara olup, insanlar da dünyevilikten nirvanaya ulaşmaya çabalıyorlardı. Samsara'nın tekerlek biçiminde temsil edildiği bilinmekte olup, bir zaman çarkının da bir ilahı bulunduğu ve Uygurlar başta olmak üzere bu zaman çarkını da bir çift ejderin çevirdiğine inanılmaktaydı. Ayrıca dünyayı taşıyan bir takım unsurlar bulunmaktaydı. Bahsi geçen Burgut Abidesi'nde olduğu gibi bunun bir kaplumbağa olarak kabul edildiği gibi, öküzün veya bir ejdarhanın da dünyayı taşıdı̆̆ııı düşünenler olmuştur. (Çoruhlu, 2011b:99, 110-112).

Türkler Şamanizm denilen bir inanca sahiptiler. Bu inanışta, şaman ya da kam adı verilen din adamları var olup, bunlar Tanrıyla insanlar arasında birer elçi görevi görürlerdi. Bu dini terime Tengricilik denilmekteydi. Genel itibarıyla, Şamanizm inancında totemizm, ata kültü, hayvan ve doğa kültleri iç içe geçmişti. Eski Türk mitolojisinde de, tıpkı Yunan mitolojisinde olduğu üzere birçok tanrı ve ruh olduğu bilinmektedir. Bunlar da, gök, yer, su ve atalar kültü ile ilişkilidirler. (Çoruhlu, 2011b:15, 17). 


\section{Eski Türklerde ve Antik Dönemde Tanrı ve Tanriçalar}

Zeus (Jupiter), Tanrlların tanrısı, tanrıların ve insanların babasıdır. Onun, "bulutları devşiren", "göklerde gürleyen" , "şimşek savuran", "uzaktan duyulan gök gürültüsü", "keçi derisinden kalkan taşıyan", "yağmur yağdıran", "rüzgarları estiren" ve "göğe gökkuşağını asan" gibi sıfatları vardır. Zeus, evrenin egemenliğini eline geçirdikten sonra Olympos'a taht kurar, oğlu demirci Hephaistos'un yaptığ krallık asasını taşır. Bu Tanrının, ölümlü ölümsüz birçok sevgilisi olmuştur. (Cömert, 1999:24)

Türkler de, göğ̈̈n tanrı olduğuna, tanrısal ruhların da gökte yaşadığına inanmışlar ve göge tapmışlardır. Onlar atalarının ruhlarının, kendilerini hep koruduğuna inanmışlar ve atalarının küçük heykellerini diğer tabirle tözlerini yapmışlardır. Böylelikle atalarının ruhları o tözlerde yaşayacak ve onları koruyacaktır. Türkler, Gök Tanrı veya ruhlarla bir şaman sayesinde iletişime geçmişlerdir. Eski Türklerin ve Moğolların inancı olan Tengricilikte, dünyanın merkezinde durduğuna, yer ve gök alemini birleştirdiğine inanılan bir "Dünya ağacı" bulunur. (Ç.1). Şamanlar da, bu ağaçtan tırmanarak Gök Tanrıya ulaşırlar. Bu Tanrı Ülgen Bay'dır. (Deveci, 2013:795-810).

\section{Ç.1: Dünya Ağac1.}

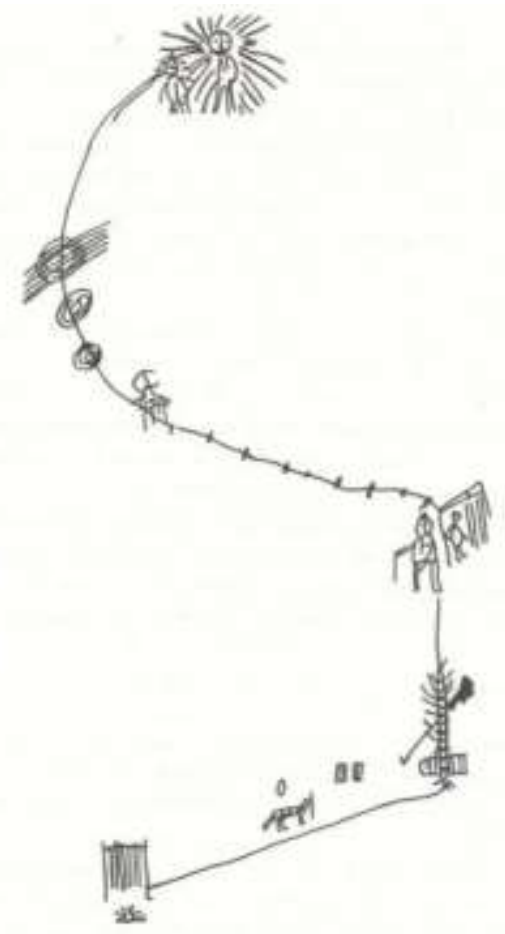

(Çoruhlu, Y. 2011b: 29)

Altay Türklerinde de en büyük tanrı olarak Kayra Han'ın kabul edildiği bilinmektedir. Dünyada var olan her şeyi yaratan da O'dur. Altay Türklerinde Kayra Han'nın oğlu olarak bilinen gökyüzünün hakimi, iyilik ve merhamet tanrısı ve yeri göğü yaratan Ülgen Bay'dır. O da Zeus gibi şimşek çaktırıp, yıldırım düşürür. Bolluk ve zenginlik kaynağı kabul edilir. Göktanrı kabul edilen Ülgen'in oğullarından birinin yırtıcı bir kuş olması, akla Türk sanatında sıkça rastlanılan kartal akla getirmektedir. (Aldemir: http://arkeopolis.com/turk-mitolojisinde-tanrilar-ve-ruhlar/ ; Çoruhlu, 2011b:28, 106).
Sümerlerde göktanrısı Anu olarak bilinirken, Enlil'ede Hava Tanrısı diyenler olmaktadır. (Mccall, 2011:39-43 ; Kramer, 2001 ; http://www.cnokta.com/sumerler/)

Yakut Türklerinde gökyüzü tanrısı ve ilk insanı, ay, y1ldız, güneş ve dağları yaratan tanrıya Ayı̆̆ Han veya "Ürüng Ayı1 Toyon" denilmiştir. (Aldemir: http://arkeopolis.com/turk$\underline{\text { mitolojisinde-tanrilar-ve-ruhlar/) }}$

Mezopatamya uygarlıklarında da, özellikle tanrılar ve siyasi yöneticilerin önemi tartışılmazdı. Mezopotamya kültüründe özellikle Sümerlerde de, Tanrı ve Tanrıçalar, koruyucu yararl1, kötü ya da yararsız olarak simgelendirilmekteydi. (Şenyapıl1, 2003:20 ; Yücel, 2016:30). Tanrlların üstünlüğ̈̈ bütün uygarlıklar için geçerliydi. Sümerlerde sudan yaratılan eril Gök (An) ve dişil toprak Nin-Hursag ile (Ki) birleşip havayı yani Tanrı Enlil'i yaratmıştır. (Yücel, 2016:24). Sümer mitolojisi oldukça geniş ve kapsamlı mitolojik sahne ve temaları ile meşhurdur. Su Tanrısı Enki'den Güneş Tanrısı Utu'ya kadar tanrılar, hizmetkarlar, sunu sahneleri ,bitki, tanrı ve tanrıçaları gibi geniş bir yelpazeye sahip olmuşlardır. (Kramer, 2001:84; Moscati, 1985; Mccall, 2011:39-43 http://www.cnokta.com/sumerler/). Aslında Tanrı inanışları çok daha eski tarihlerde, ilksellere kadar inmektedir. Bunu gerek Avrupa sanatında, gerekse Türklerde görmek mümkündür. Bu kadın figürleri öncelikle akla "Ana Tanrıça Kültü"nü getirmektedir. Nitekim bunlar, bereket, üreme gibi olguları ifade etmektedir. (Kuban, 2014:101) Antik Mitolojide bilinen ilk toprak ana Gaia'dır. Ayrıca tarihler otuz bin yıl öncesini gösterdiğinde, karşımıza Avusturya'daki Willendorf Venüsü çıkmaktadır. Bu diğer ismiyle ise Kybele motifleridir.(Cömert, 1999:17; Şenyapıl1, 2003:1) Kybele benzer özeliklere sahip önemli bir Anadolu tanrıçasıdır. Sümer'de bu tanrıçanın adı Büyük Ana Tanrıça Ninhursag'dır. Kimisi ona toprak anlamındaki "Ki" diye tapard1. (Cömert, 1999:57; Yücel, 2016:28). Sümerdeki diğer önemli Ana tanrıça Nimmah olarak da adlandırılır.(Mccall, 2011:39-43 ; Kramer, 2001 ; http://www.cnokta.com/sumerler/

Tekrar Antik Yunan'a döner isek, Hera (Iuno) ile karşılaşılmaktadır. Zeus'un eşi hem de kızkardeşi olan bu Tanrıça kıskançlığı, inatçı ve kavgacı ruhuyla bilinmektedir. Güzelliğine de oldukça düşkündür. Onun, evlilik ve gebeliğin koruyucusu olduğuna inanılır. Tavus kuşu ve nar, işaretleri arasındadır. (Cömert, 1999:26-27). Türklerin inandı $\breve{g}_{l}$ dişil ruh olarak ise Tanrlça Umay gelmektedir. Onun Hera'ya göre daha sevecen olduğu düşünülmekte ve kadın ile çocukları koruduğuna inanılmaktadır. (Deveci, 2013:795810). Yapılan kimi sanat eserlerinde, örneğin kadın heykellerinde genelde başında taca benzer dilimli bir başlık taşır. (Çoruhlu, 2011b:227 ; İskenderzade, 2010:256-269). Ayrıca doğum tanrıçası, evlilik tanrıçası ve güzellik tanrıçası olarak da kabul edilir ve bu son özelliği ile de Aphrodite’i hatırlatır. Kendisine bazen Umay Ana-Ayısit veya Ayzit Hatun da denilir. (Aldemir: http://arkeopolis.com/turkmitolojisinde-tanrilar-ve-ruhlar/).

Athena (Minerva) veya öteki adıyla Pallas, doğru ve haklı olan savaşın tanrıçasıdır. Bakireliğe verdiği önem ile tanınan tanrıça, güzelliğini de önem vermektedir. Genellikle silahlı ve kalkanlı olarak betimlenen Athena bilgelik sıfatına da sahiptir, simgesi de baykuştur. (Cömert, 1999:27-28). Sümerlerde Enki'nin de bilgelik tanrısı olduğu bilinmektedir. 
(Mccall, 2011:39-43; $\quad$ Kramer, 2001 http://www.cnokta.com/sumerler/)

Apollon (Apollo), kendisine yakıştırılan Phoibos sıfatı dolayısıyla 'parlak, 1şık saçan, 1şıtan' olarak tanınır ve en çok güneş tanrısı olarak bilinir. Oysa ki asıl güneş tanrısı Helios'tur. Apollon, okçudur, altın kılıçlı altın saçlı bir tanrıdır Kurt, kuğu veya karga ise simgeleri arasında yer alır. (Cömert, 1999:29-30). Helios'un bahsi geçtiği üzere asıl güneş Tanrısı olduğu ve şahlanan dört atın çektiği arabayla, güçlü ve yakışıklı bir genç olarak tasvir edildiği bilinmektedir. (Cömert, 1999: 47). Sümerlilerin Güneş tanrısı da Utu olarak tanınır. (Mccall, 2011:39-43 ; Kramer, 2001 ; http://www.cnokta.com/sumerler/)

Tanrıça Artemis'in (yani Diana) kardeşi Apollon Güneş'le bir tutulurken, Artemis ise Ay'la bir tutulmaktadır. Artemis temalarında ok ve yay, kimi zaman da at ve arabayla betimlenmektedir. Bazen kendisine bir köpek ve geyik eşlik eder. Altın bir yaya sahip tanrıça, avcı ve bakireliğine düşkün bir tanrıçadır. Ay simgesi olarak bazen bir hilal taşırken, bazense meşale taşır. Efes'in Artemis'i Anadolu'yu simgeleyen ve dolayısıyla bereket sembolünü ifade eden önemli bir tanrıçadır. (Cömert, 1999:30-31). Ayrıca Helios'un kızkardeşi olan Selene de ay'l simgelemektedir. Bazen tek başına, bazense at üzerinde gösterilir. $\mathrm{O}$ da yarımay ve bir meşale taşımaktadır. (Cömert, 1999:48). Sümerlilerde, Nanna'nın da Ay tanrısı olduğu bilinmektedir. (Mccall, 2011:39-43; Kramer, 2001 http://www.cnokta.com/sumerler/)

Ares ( Mars), Athena'dan farklı olarak çılgın bir savaşçı ve zalim bir Tanrıdır. Amaçsızca kıymayı sever. Bu bağlamda en önemli işareti mızraktır.

Hermes (Mercurius), çobanların ve hayvan bereketliliğinin tanrısıdır. Bunun neticesinde kimi zaman bir koç taşırken gözlenir. $\mathrm{Bu}$ niteliğini anımsatan görünümü, Hermes Kriophoros'tur (Koç Taşıyan Hermes). Ayrıca, Tanrının habercisi görevini de üstlenmiştir. Kendine Ruhlar Klavuzu lakabı verilmiştir. Ticaretin tanrısı olduğu da söylenir. Ayağında kanatlı sandalları ve elinde tuttuğu iki yılan sarılı asası ile betimlenebilir. (Cömert, 1999:31-33).

Türklerin Tanrısı olan Mergen de, zekası, okçu kişiliği ve bilgeliğiyle tanınır. Hermes de bilgeliğiyle ün saldiğı için ikisi arasinda benzerlik kurulabilir. Uygur'un Tanrısı Mergen'in okçuluk simgesi çift kanatla betimlenebilir. (Deveci, 2013:.795-810). Tanr1 Ülgen'in emrinde olan ve bir ruh olarak tanınan Yayık için de haberci rolünü oynadığını söylemek mümkündür. Çünkü Tanrl ile insanlar arasında rehberlik etmek gibi bir görevi vardır. (Çoruhlu, 2011, s.32). Gökte yaşadığına inanılan ve yine Ülgen'nin elçisi kabul edilen Utkuuçi'nin de görevi Kurbanları göğe Ülgene götürmektir. (Aldemir: http://arkeopolis.com/turkmitolojisinde-tanrilar-ve-ruhlar/).

Hephaistos (Vulcanus), Ateş tanrısıdır. Özellikle madenlerle uğraşmayı sevmesinden dolayı maden işçisi lakabı takılmıştır. Hestia (Vesta) da, ateşle ilgilidir. Aile ocağını, daha geniş anlamda insan topluluğunu, kenti simgelemektedir. (Cömert, 1999:.34). Türklerde de Odana yani ateş veya Ocak, bir dişi tanrıça olarak tanınır. (Deveci, 2013:795-810).

Aphrodite (Venus), güzelliği ve sevgilileri ile ünlü Tanrıça, genellikle eros yani Aşk ve Sevgi ile birlikte anılır.
Aphrodite'nin bilinen simgeleri arasında; güvercin, serçe, keçi, istiridye, yunusbalı̆̆l, kaplumbă̆a gibi hayvanlar yer almaktadır. Bazen Umay Ana ile güzellik unsuru bakımından ilişkilendirilmektedir. Ayrıca Sümer de İnanna, Aşk Tanrıçası olarak bilinmektedir.

Poseidon (Neptunus), Denizlerin tanrısıdır. Ayrıca toprağın da sahibi kabul edildiği olmuştur. 'Toprağın efendisi', 'yeri sarsan' lakapları ile tanınır. Özellikle elindeki üç çatallı zıpkını ile görülür. Bununla yapraktan, kayadan su fişkırtması nedeniyle ona su kaynakların tanrisı da denmiş, atın yaratıcısı ve evcilleştiricisi kabul edilmiştir. Su ile bağlantı kurabileceğimiz Sümerlerden de, su tanrisı Enki'yi saymak mümkündür. (Cömert, 1999: 34, 38. ; Mccall, 2011:39-43 ; Kramer, 2001 ; http://www.cnokta.com/sumerler/)

Hades ( Pluton) adı , 'görünmez' anlamına gelmektedir. Bu tanrıyı görünmez kılan şey taşıdığı başlık olmaktadır. Ölüler ülkesinin adına da Hades denilir. Yer altı ve cehennem tanrısı olarak da kabul edilir. Ayrıca, ahlakı bozan ve bu tarzdaki insanları cezalandıran Erinys'ler de, cehennem tanrıçalarıdır. Onların işareti yılandır. (Cömert, 1999:.35, 39, 57). Türklerin (Etügen) Ötegen'i de yer tanrıçası olmasıyla benzerlik taşır. (Deveci, 2013, ss.795-810). Türk ve Moğol mitolojisinde ismi geçen Etügen, hayvanları ve toprak ile ilgili tüm ürünleri koruyan da bir tanrıçadır. Aslında Yer Tanrıçası ile doğum ve üretim arasında bir bağ kurulmuştur. Erlik Han da yer altıtanrısıdır, ancak şeytanla eş tutulmuş olup Göktanrıdan sonra gelmektedir. (Kuban, 2014:54.). Sümerlerdeki Ki de, yer altı tanrısıdır. Yer altında yaşayan bir ruh olan Albastı $d a$, ölüler alemini temsil eder. (Aldemir: http://arkeopolis.com/turk-mitolojisinde-tanrilar-ve-ruhlar/. ; Çoruhlu, 2011:.55. ; Mccall, 2011:39-43 ; Kramer, 2001).

Dionysos (Bacchus), üzümü ve şarap yapma sanatını bulan bir tanrıdır. Her gittiği yere asmasını götürür. Bakkha'lar, onun alayından olup, Dionysos adına dinsel törenler yaparlar. Çoğunluk sarmaşık, asma yaprağı ve bir kadehle betimlenen Dionysos'un hayvanları aslan, kaplan boğa ve keçidir. (Cömert, 1999: 41-43). Yunan kültüründe Dionysos kutlamaları yaşam zevkleri üzerine kurulu olup, cinsellik içeriklidir. Üzüm toplama ve bağ bozumu törenleri hep onunla ilgili tutulur. (Yücel, 2016:.13). Ayrıca onun törenlerinde şarap içilmesi Hristiyanlık ayinlerde sunulan içkiyle de bağdaştırılmaktadır. Elinde tuttuğu kadeh, Eski Türklerdeki balbalların da elinde kadeh tutmasını akla getirmektedir. (Jung, 2009:143).

Tanrıça Demeter ( Ceres), anlayışlı ve iyi bir tanrıça olarak tanınır. Başaktan bir demet ile asa ve domuz yavrusu ile yılanın da onun simgeleri olduğundan bahsedilir.

Bunlar dışında gök ve atmosferle ilişkili bazı tanrılar da bulunmaktadır. Örneğin Eos, şafak'1 simgeler. Astraios, Şafak tanrıçası Eos'un kocasıdır. Kimi yıldız ve rüzgarların babasıdır. Heosphoros ve Phosphoros sabah yıldızını, Hesperos ise akşam yıldızını temsil eder. Eos'la Astraios'un oğulları olduğu söylenen başlıca rüzgarlardan Boreas; Poyraz ya da Yıldız dediğimiz kuzey rüzgarıdır. Zephyros, Kareyel denilen batı rüzgarını, Euros; Doğu rüzgarını, Notos; Lodos'u, Harpya'lar da; Kasırga'yı simgelemektedir. (Cömert, 1999:39-40, 48-49 ).

$\mathrm{Bu}$ arada dikkat edildiğinde Avrupa mitolojisindeki çoğu Tanrı ya da Tanrıçanın simgesi olan bir hayvan figürüne rastlanılmaktadır. Dolayısıyla tıpkı Türklerde olduğu gibi 
hayvan motifleri, bir çok uygarlık mitinde benzer bir şekilde yerlerini ve önemlerini korumuş durumdadır.

\section{Eski Türklerde Bazı Heykeller, Kozmografya ve Kutsallık Simgeleri ile Hayvanlar ve Hayvan Üslubu Üzerine}

Atlı ve göçebe kültürü olarak değerlendirebileceğimiz gerek Hunlar gerekse Göktürklerde, çok sayıda taş heykele veya balballara rastlanmaktadır. Özellikle Bilge Kağan, Kültiğin ve Tonyukuk'a ait anıt biçimli heykel diyebileceğimiz unsurlar, bunlar arasında bilinen en önemli örneklerdir. Türklerde atalar kültü ayrıca önemli olup, özellikle ölen kişiye saygı duyulmuş, onu veya öldürdüğü kişileri simgelemek adına bu tarz heykel veya balballar dikilmiştir. İskit döneminden başlayarak bu tür düzenlemelerin yalnızca mezar çevresinde değil, ayrıca törenlerde veya anma mekânlarında yapıldığı da dikkate alınmalıdır. Ancak çok eski tarihlere inildiğinde, tarih öncesinde dikilmiş olan menhir örneklerinin de, balballarla ilişkili olabileceğ $i$ düşünülmektedir.(R.3).

\section{R.3: Tarih Öncesinden bir Menhir.}

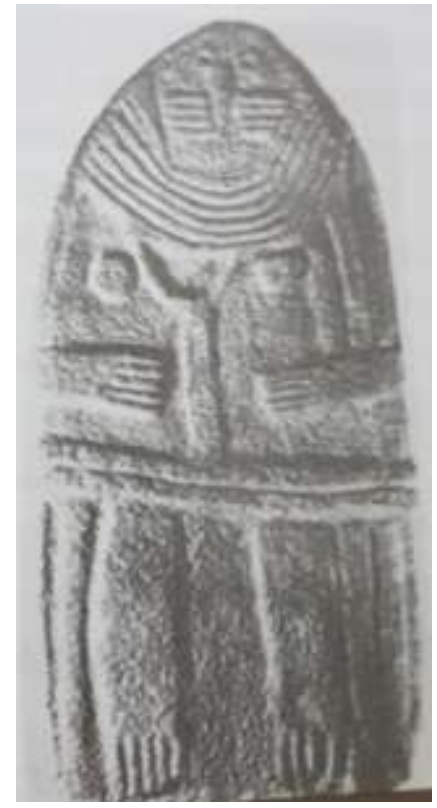

(Jung, 2009:.233).

Bu bağlantılardan hareketle, balbal dediğimiz unsurlar (R.4) çoğunlukla ayakta, bazen oturur vaziyette gözlenebilir. Dikkat edildiğinde bunların çoğunluğunda, ellerinde şarap benzeri bir kadeh taşıdıklarına tanıklık edilmekte olup bu da akla, Antik Yunan mitolojisinde Dionysos kültündeki şarap ve kadeh ilişkisini getirmektedir. Hatta Demeter'in de bazen elinde kadehle gösterildiği örnekler mevcuttur. Bu kadehler ne için yapılmaktaydı? Bunların and törenleri veya ayin sunumları için eklendiği düşünülmekte, bazense düşmanla yapılan antlaşmayı simgelediğinden bahsedilmektedir. Kimine göreyse, ölümsüzlüğü temsil ettiği, ölümsüzlük dileği olduğu söylenmektedir. (Çoruhlu, 2011a:.158-159,221 ; İskenderzade, 2010:256-269).
R.4: Balbal Örnekleri.

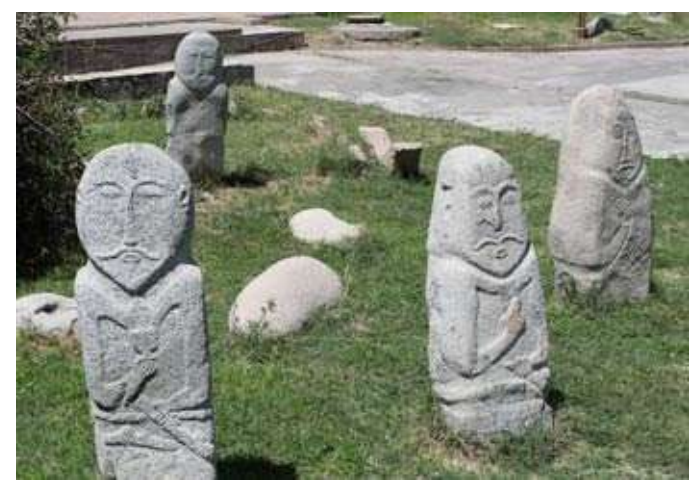

(http://www.serenti.org/turklerin-tarihe-biraktigi-iz-balbal/)

Hunlar veya Göktürklerin bir de "geyik taşları" denilen ve üzeri geyik vb hayvanlarla süslü bazı dikilitaşları olduğu da bilinmektedir. Göktürklerin cenaze törenlerinde geyikleri de kurban etiği düşünülürse, belki de buradan etkilenerek bu taşların yapılmış olabileceği düşünülebilir. (Çoruhlu, 2011, s.159. ; Esin, 2004:19; İskenderzade, 2010:256-269).

Yerleşik yaşam kültürüyle tanınan Uygur Türkleri de, inanç olarak Budizm veya Manizm ile ilgilenmişler ve heykel örnekleri de büyük ölçüde bu yönde gelişmiştir. (Çoruhlu, 2011a:247, 298-299).

Eski Türklerde evren kozmografyası vb. bir takım unsurlar, önem verilen ve hatta tapınılan unsurlar olarak bilinmektedir. Örneğin Göktürklerde daha önceden de bahsi geçen Kültigin abidelerinin ayrıca evreni de sembolize ettiği söylenir. Bu bağlamda dünyayı sırtında taşıdığına inanılan kaplumbağa ya da ejder motifleri oldukça önem arz etmektedir. (Çoruhlu, 2011a:178-181).

Göktürkler başlarda evreni dikdörtgen veya silindir biçimli olarak hayal etmişler ve kubbeli çadırlar olarak düşünmüşlerdir. Uygur kozmografyasında da, yeryüzü dört tarafi okyanusla çevrilidir ve düz bir kara parçasıdır. Yeryüzünün ortasında ise kutsal dağlardan "Sumeru Dă̆ı" bulunur. Tıpkı Zeus'un Olympos Dă̆l gibi.Bir süre sonra gök kubbenin yerini, önemi açısından kutupyıldızı alır. Hatta büyükayı takımyıldızının da göktanrıya benzeyen bir tanrı olduğuna inanılmıştır. Ay ve güneşin de dünyanın etrafında döndüğü düşünülmüştür. Gökyüzünde yıldızları taşımakta olan, dönen bir tekerleğin varlığına inanılır. (Esin, 2004, ss.114-121). Kısaca Güneş, ay ve yıldızlar tapınılan unsurların başında gelmektedir. Ayrıca güneşi simgeleyen madeni halkalar da önem taşımaktadır. Sümerdeki Işstar ise, yıldız anlamına gelmekteydi. Kimi zaman Situri de yıldız veya ay tanrıçasını temsil ederdi. (Çoruhlu, 2011b:23 ; Şenyapıl1, 2003:4).

Türklerde kullanılan oniki hayvan simgesi de takım yıldızını temsil etmekte olup, ayrıca hayvanlar yılları, ay ve günleri gösterir. Bu hayvanlar; sıçan, öküz, pars-kaplan, tavşan, ejder, yllan, at, koç, maymun, horoz, köpek ve domuzdur. (Esin, 2004:117-119).

Güneş, Antik Yunan mitolojisinde de önemli olup, Akla Helios ile Apollon'u getirmektedir. Ay'ın erkek, güneşin de dişi olduğu düşünülmüştür ki, bu bağlamda güneş Umay Ana ile ilişkilendirilmişti. Ay ile ilişkilendirilen Tanrıçalar ise Antik dönemden Artemis (Diana) ve Selene'dir. (Çoruhlu, 2011b:24, 26). Gece, kış mevsimi, su veya çift sayılar da dişillik kavramıyla bağdaştırılır. Türklerde de kara yılan, ve 
kaplumbağa takım yıldızıyla da özdeșleştirilir (Esin, 2004:26.)

Mevsimleri ilişkilendirmek gerekirse, aslında oldukça eski tarihlere inmek mümkündür. Kökeni belki 3000 yıl öncesine dayanan Stonehenge'de, mevsimler bereket törenleri olarak kutlanırdı. Nitekim yaz gündönümünde Stonehenge'de güneşin doğuşu ayrıca önem arz ederdi. (R.5). (Jung, 2009:109)

\section{R.5:Stonehenge'de Güneşin Doğuşu}

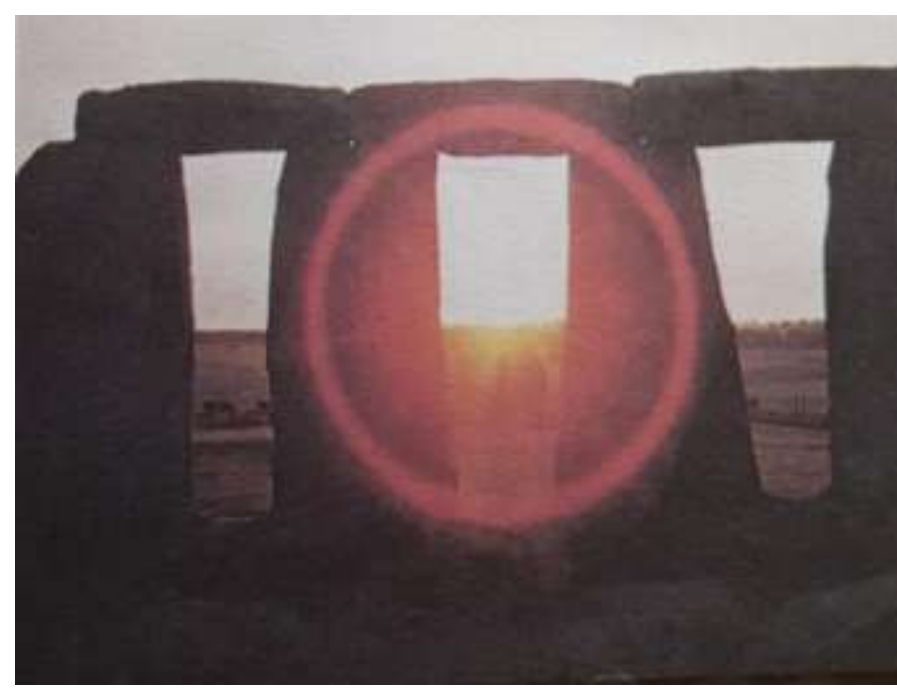

(Jung, 2009:.109)

Uygurlarda da kare içinde daireler, dört yön simgeleri, dünya ağacı tasviri dikkati çeken başlıca unsurlardır. Dört yönü temsil eden haç'ın, Uygurlarda gözlemlenmesi de ilginçtir ve dört yönü de ilahlar temsil etmektedir. Örneğin bunlar içinde, Baş Tanrı Cakraşamvara Heruka ve karısı bulunmaktadır. (Esin, 2004:83) Ayrica bir Yunan tanrıçasının haçı andıran heykeline de tanıklık edilmiştir; tarihsel olarak MÖ. 3.bin dolaylarina ait olduğu söylenmektedir. (R.6). (Jung, 2009:107).

R.6: Yunan Tanrıçasına Ait bir Haç.

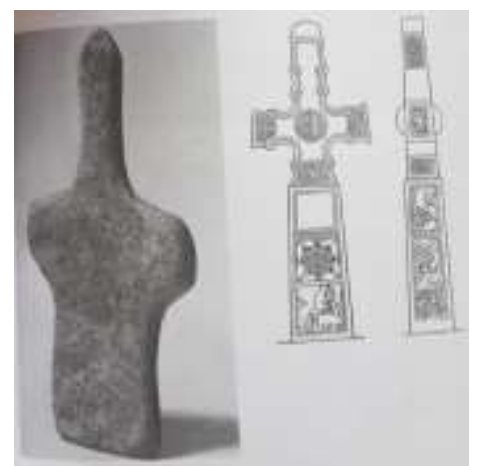

(Jung, 2009:.107).

Dă̆, su tanrıları, ateş ve ă̆aç da Türklerde kutsaldır. Bu kutsal nesneler ile hükümdarlar, göktanrının yeryüzündeki temsilcileridir. Göktanrı simgesi içinde yurt da denilen çadırlarda kabul edilir. Kayra Han, Ülgen Bay veya Zeus bu kutsallıklarla özdeş Tanrılar arasındadır. Örneğin ateş denilince akla hemen Ateş Tanrısı Hephaistos gelmektedir. Dağ-Ağaç ya da orman ile ilişkili mitolojik antik varlıklar olarak Oreas'larıyani Dăg perilerini, Auloniad'lart yani Vadi perilerini, Dryad'ları yani korudukları ăgaçlardan pek ayrılamayan perileri, Ekhoları yani dă̆ perilerini düşünmek mümkündür.

Ayrlca Türklerin önemli simgesi olan ă̆aç veya dünya ă̆acı da, Yunan mitinde önemini korumaktadır. Örneğin bir mühür üzerinde görülen bir resimde, Demeter ile Persophone,kutsal ăgacı tutmaktadırlar. Hatta adına da "ölümsüzlük bahçesi" denilmiştir. (R.7). (Campbell, 2003:19. ; Cömert, 1999:54 ; Çoruhlu, 2011b: 22).

\section{R.7: Ölümsüzlük Bahçesi}

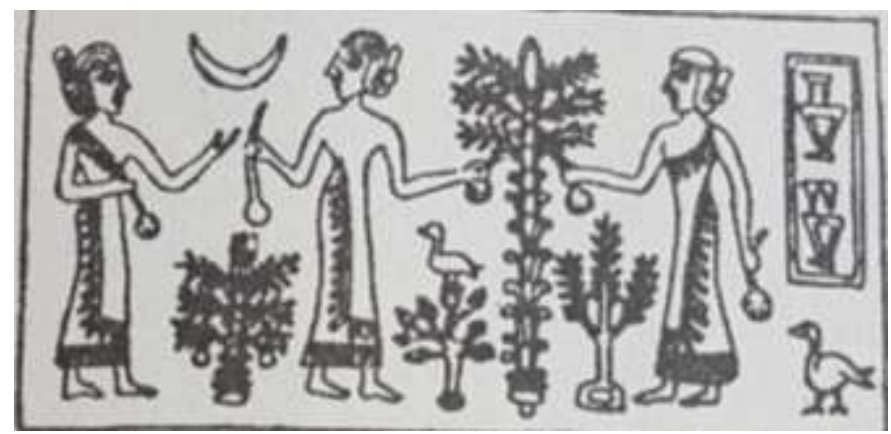

(Campbell, 2003:19).

Uygurlarda, ă̆aç verimlilik simgelerken, yemişleri de bodhisattvalar yani rahipler veya hükümdarı betimlemektedir. Mani ve Budizm dinine inanan Uygurlarda, evrenle ilgili bir diğer simge de lotus çiçeğidir. Yani nilüferdir ve genellikle Budha'ya adak olarak sunulur. (Çoruhlu, 2011b:100,307 ; Esin, 2004:.44).

Doğum, ölüm okyanusu ya da nehri demek olan ve nirvanaya ulaşmayı simgeleyen Samsara'nın varoluş tekerleği, Cakra olarak adlandırılır. Su veya okyanus temaları düşünüldüğ̈̈nde benzer şekilde, Antik dönemin su Tanrisl kabul edilen bir diğer ismi olan Okeanos akla gelmektedir. Ayrıca başında nehir tanrılarının sıfatları kabul edilen boğa boynuzu veya deniz tanrılarının işareti sayılan kabuklu hayvan ayağı da görülür. Nympha'lar da, kırlarda, sularda, ormanlarda yaşayan peri tanrıçaları olarak önemli figürlerdir. Nympha'lar ölümsüz değillerdir. Sirenlerin de ölüm tanrıçaları oldukları, denizlerde yaşadıkları, kuş vücutlu ve kadın başlı varlıklar oldukları kabul edilir. Tasvirlerinde belden yukarısı kadın, belden aşağısı balık olarak tasvir edilirler. (Cömert, 1999:50, 52 ; Çoruhlu, 2011a: 306-307).

Türklerin hayvanlarla ilişkileri ve hayvan üslubu, her zaman önemli olmuştur. MÖ.5 ila 3.yy. arasında görülen üslupta; çevredeki hayvanlara, doğanın sırlı yaşamını simgeledikleri için de önem verildiği bilinmektedir. Hayvan üslubunu araştıranlar bu üslubun başlangıcını İskitlere kadar indirmişlerdir. Hatta Yunan natüralist sanatındaki süslemeli unsurlar ve bunların üsluplaşmış haliyle ilişkilendirilmeleri de söz konusu olmuştur. Örneğin Kırım'da Iskitlere ait hayvan motifiyle süslü vazo ile benzer bir Yunan vazosu karşılaştırıldığında bu benzerliğe tanıklık edilecektir. (R.8). (Kuban, 2014: 54, 63, 69). 
R.8: İskitlere Ait Hayvan Motifiyle Süslü Vazo ile Benzer bir Yunan Vazosu

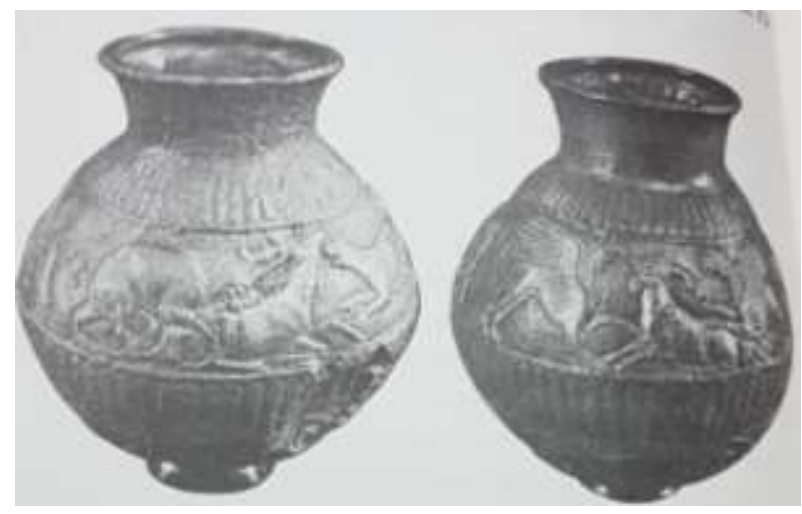

(Kuban, 2014:64)

Hayvanlar, koruyucu ruhlar olarak da kabul görmüşler ve hatta onların kılığına bürününce, onun gücüne sahip olunacağına inanılmıştır. Bu üslup da şamanizmin etkileri olduğu da düşünülmektedir. Türk kozmolojisi ve mitolojisi de bu sembollerle içiçe geçebilmektedir. Bu üslup Mezopotamya kültürlerinde de gözlenmektedir. Bu üslupta özellikle; av sahneleri, hayvanla hayvan veya hayvan-insan mücadele betimlemelerine sıkla rastlanılmaktadır. Ayrıca masal veya efsanevi yaratıkların varlı̆̆ 2011a:163).

Hayvanlart simgesel anlamlart ile daha derinlemesine incelemek de mümkündür. Bunları benzerlik bağlamında Antik Yunan mitleriyle tekrar hatırlatmakta fayda vardır

Türklerin önem verdiği hayvanlardan birisi olan ejderha motifi, bereket, güç, veya bolluğu simgelediği kadar kimi zaman Gök veya Su tanrısı ya da toprak tanrısı ile eşdeğer tutulmuştur (Esin, 2004:31, 35)

Eski Uygurlarda kötü hayvanlar arasında kabul edilen yılan, aynı zamanda yer altı tanrısı Erlik ile de eşdeğer tutulmuştur. Bu figür, Antik mitolojide de sıklıkla görülen bir figürdür. Nitekim Hermes'in iki yılan sarll asası bulunduğu bilinmektedir (Cömert, 1999:.33 ; Çoruhlu, 2011b:183 ; Tokyürek, 2013:221-281).

Türklerde beylik, kut simgesi olarak kaz veya kuğu önem kazanırken, altın tavuk ve horoz da astrolojik simgelerden kabul edilmişlerdir (Esin, 2004:.37, 41 ).

Budizm'de tanrılarla ilgili olduğu düşünülen dağ keçisi, genellikle hanedan arması olarak da kullanılmıştır. Bunun en güzel örneğini Göktürklerde görmekteyiz.

Koç da, eski Türklerde Gök Tanrı'ya sunulan kurbanlar arasındadır. Ayrıca gökle bir tutularak göğü ve kuvveti simgelemiştir (Çoruhlu, 2011a:179; Tansü \&Güvenç, 2015:203-218).

Kuş simgesi, Türk kozmoloji ve mitolojisinde önemli yer tutar. Yeryüzündeki insanlara can verdiği kabul edilen kuşların, sonsuzluğu simgelediği de kabul edilir. Yeryüzünde doğan insanlara can veren bu kuşlar aynı zamanda yaşamın sonsuzluğunu ve dönüşümünü de simgelemektedir.
Göktürk Dönemi insan figürlü heykellerin elinde de görülebilen kuş tasvirleri, öbür dünya, ölüm ve ruh ile ilintili bir simge kabul edilir. (Ögel, 2014,Türk Mitolojisi, C.I-II).

Türklerde, boğanın da dünyayı sırtladığı ve yaşanan depremlere bunların sebep olduğu düşünülmüş ve dünyayla eş değer tutulmuştur. Dolayıyla yer ile ilişkili bir hayvandır. Kahramanlıkla da özdeşleştirilir. Ayrıca boğanın sesi, Budha'nın sesine benzetilmiş ve bu bağlamda önem kazanmıştır. (Çoruhlu, 2011a:.314) ; Çoruhlu, 2011b:168) ; Tansü \& Güvenç, 2015:203-218 ; Tokyürek, 2013:221-281).

Bilindiği üzere boğa, Antik mitolojide Poseidon'un hayvanidır. (Campbell, 2003:57.)

Anka (Simurg) kuşu, her şeyi bildiği kabul edilen bir hayvandır. Bilgi ăgacının dallarında yaşar. Mısırlılarda adı Phoenix, Iranlılarda Simurg, Arap-İslam kültüründe karşıllğ da genelde Zümrüdüankadır. (Deveci, 2013:795-810).

Kartal ya da çift başlı kartal oldukça önemli ve s1k rastlanılan bir canlı olup, göktanrıyı simgelemektedir. Genellikle de, dünya ağacı tepesinde gözlenir. Göktürk ve Uygurlarda da, hükümdarları temsil eder. Ruh ve adalet simgesi olduğu kadar, Güneşi de temsil eder. Hakimiyet, güç ve kuvveti ifade ettiği de bilinen kartal motifi, İslam sonrası devletlere kadar geniş bir kullanım alanı bulmuştur. Birçok devlet ve milletin simgesi olan çift başlı kartalı, günümüzde halen görmek mümkündür. Çift olması gücü artıracağı inancıyla ilişkili olabilir (Çoruhlu, 2011b:156. ; Tansü \& Güvenç, 2015:203-218).

Sıkça rastlanılan bir diğer hayvan ise aslan motifidir. Savaşı, zaferi ve iyiliği simgelediği düşünülür. Aslan tanrısal bir hayvan olarak Batı Türk Dünyası'nda karşımıza çıkmaktadır. Budizm'de aslan, tanrı sembolü ve hükümdarın oturduğu tahtı simgelemektedir. Yunan mitinde aslan, kaplan, boğa ve keçinin Dionysos'un diğer simgeleri arasında olduğundan söz edilmiştir (Cömert, 1999:43. ; Çoruhlu, 2011b:159-160. ; Tansü \& Güvenç, 2015:203-218).

Türklerin olmazsa olmaz hayvanı attır. Şaman gökyüzüne onunla çıkar. Göktanrıyı simgeler. Yas işareti olarak kuyruğunun kesildiği veya düğümlendiği de bilinmektedir. Hatta kurganlarda, ölüye hizmet etsin diye beraber gömüldükleri de bilinmektedir. Kısaca at ile gökyüzü arasında bir bağlantı olduğuna inanılır. (Çoruhlu, 2011b:163-164. ; Tansü \& Güvenç, 2015:203-218.). Eski Uygur döneminde özellikle on iki hayvanlı Türk takvimi içinde de at kullanılır. Bu at yılında karışıklıkların çıktı̆̆ kışın soğuk ve yağışlı olduğu düşünülür. Antik Yunanda ise, Artemis'in simgesi at iken, bazen ona geyik ve bir köpek eşlik eder. Posedoin'un da atı yarattı̆̆ ve evcilleştirdiği söylenir. (Cömert, 1999:30-31; Tokyürek, 2013:221-281).

Türklerde kurt ve attan sonra önemli bir diğer hayvansa geyiktir. Yine gök ve yerle özdeşleştirilen bu hayvan, hükümdarlıkla da ilgili olup denizle de ilişkilendirilmiştir. Eski Uygur metinlerine göre karga, günahkar canlıları cezalandıran varlıklar arasında sayılır (Çoruhlu, 2011b:165166 ; Tokyürek, 2013:221-281).

Baykuş için, Uygurlarda kötü ve uğursuz olduğu düşüncesi hakimdir. Baykuşun Ayrıca Yunanlılarda Athena'nın sembolü olduğunu hatırlamak gerekir. (Cömert, 1999:28 ; Tokyürek, 2013:221-281). 
Bir diğer hayvan güvercin de, özellikle Uygurlarda önemli bir yere sahiptir. Güvercin, keçi ve kaplumbağanın, Afrodit'in işaretleri arasında olduğu bilinmektedir. (Cömert, 1999:37 ; Tokyürek, 2013:221-281).

Çok sık rastlanılmasa da $k u \breve{g} u$, Budizmde simgesel bir anlam ifade etmektedir. Nitekim Buddha'nın yürüyüşü kuğunun yürüyüşüne benzetilir. (Tokyürek, 2013:221-281). Yine, kurt, kuğu ve karganın da, Apollon'un işaretleri olduğu bilinmektedir. (Cömert, 1999:30,127).

Dünyayı sırtında taşıdığına inanılan kaplumbağa, yer ve gök simgesi olarak kabul edilebilir. Özellikle de yukarıda da değinildiği üzere, I. Göktürk Kağanlığı döneminde dikilmiş olan Burgut yazıtının tepeliğinde dişi kurt ve onun doğurduğu bebek yani insan yavrusu resmedilmiş olup, bu durum Türk mitolojisindeki bir adamla kurdun birleşmesini simgelemektedir. Çeşitli hayvanlardan türediklerini savunan Türkler, bu hayvanların da özelliklerine sahip olduklarına inanmış ve onlar gibi davranmaya çalışmış, onların şekline bürünmüşlerdir. Dolayısıyla gök ve yer unsurlarıyla çeşitli anlamlara sahip olmuşlardır (Tansü\& Güvenç, 2015:203-218 ; Tokyürek, 2013:221-281).

Tavus kuşu da, kutsallığı sonraki dönemlere kadar süren bir hayvan olarak kabul görür. Daha çok Uygurlarda Buddha ve Bodhisattvaları temsil eder. Antik dönemde tavuskuşunun da, Hera'nın işareti olduğu bilinmektedir. (Cömert, 1999:27 ; Tokyürek, 2013:221-281)

\section{Sonuc}

İslamiyet öncesi Türk toplumları incelendiğinde, özellikle Orta Asya Türkleri akla gelmekte ve inceleme alanı olarak değerlendirilmektedir. Çalışmada, Türklerin inandığı dinler, Şamanizm, Totemizm, Mani ya da Budizm'in yanı sıra belli başı 1 Türk Tanrıları değerlendirilmiş ve bu tanrılarla Antik dönem Yunan veya Roma mitolojisindeki Tanrı-Tanrıçalar arasında benzerlikler kurulmaya çalışılmıştır. Ayrıca, yaratılış inanc1 göz önünde tutularak Türklerin özellikle kurttan türeyişinden başlanıp, dolayısıyla insanın yaratılış hikayesi Antik dönem içerisinde de değerlendirilmiştir. Gök, atmosfer, yeryüzü, deniz veya su ile ilişkili olaylar ve simgeleri anlatılırken, karşımıza özellikle Türk Kozmografyası çıkmıştır. Böylelikle evren vb. unsurlar geniş bir yelpazede anlatılmaya çalışılmıştır. Yine Antik dönem bağlantıları olup olmadıkları da değerlendirilmiştir.

Yapılan değerlendirmeler bir takım verilere ulaşmamızı sağlamıştır. Şöyle ki; Türklerin kurttan türeme efsanesine Romalılarda da tanıklık edilmiştir. Ayrıca ana tanrıça kültünün hemen hemen tüm uygarlıklardaki varlığı ve önemi ortaya konulmuştur.

Tanrı veya Tanrıçalar da, bir takım özellikleriyle özdeşleştirilmiş ve buna göre Zeus Ülgenbay ile, Hera Umay Ana ile, Apollon Sümerlilerin Güneş tanrısı Utu ile Artemis Nanna ile, Hermes Mergen ile, Aphrodite İnanna ile, Hades Türklerin Ötegen'i (Etügen) ile benzerlik göstermiştir. Dionysos ise, onunla bütünleşen kadehi ile Türklerin de balballarının ellerinde tuttukları kadeh ile benzer özellik sergilemektedir. Ayrıca Türklerin önemli simgesi olan ağaç veya dünya ağacı da Yunan mitinde önemini korumuştur. Benzer şekilde dağ, su, orman, evren inanışları da benzerlik göstermiştir.
Bütün toplumlarda olduğu gibi hayvanlar Türkler için de önemli bir yere sahiptir. Özellikle hayvanlar ya da hayvan adları dinî değerler taşıdıkları kadar, temsil ettikleri bireylerle de değerlendirilmiştir. Özellikle tanrılarla ilişkileriyse göz ard1 edilmemelidir. Zaten hayvan denilince, özellikle Türklerin hayvan üslubu yadsınamaz temalar arasında yer bulmuş olan bir konudur. Bu bağlamda, antik dönemle de bağlantılar kurulmaya çalışılarak çalışma zenginleştirilmeye çalışılmıştır.

Çalışmadaki amacımız, mitolojiyle özdeşleştirmek üzere, Türk mitolojisini biraz daha ön plana çıkarmak olmuş, mitoloji denilince akla yalnızca antik dönem veya Avrupa mitolojisi gelmesinden dolayı Türk mitolojisinin de ne kadar önemli olduğu ve geniş bir yelpazaye sahip olduğu dile getirilmeye çalışılmıştır. Bilinen bir gerçek de, Türk mitolojisindeki birçok konunun daha sonraki İslam ve diğer devletlere, hatta Selçuklu ve Osmanlı'ya kadar süren izleri olduğu gerçeğidir.

Bundan sonra asıl olarak amaçlanan ve umulansa, Türk mitolojisine Antik dönem mitolojisi kadar değer verilmesi, sıklıkla çalışma konularına kaynaklık etmesi ve hatta okullardaki mitoloji derslerinde hak ettiği yeri bulmasıdır.

\section{Kaynakça}

Aldemir, M.B. (tarihsiz). Türk Mitolojisinde Tanrılar ve Ruhlar. Arkeopolis:29.04.2018 tarihinde http://arkeopolis.com/turk-mitolojisinde-tanrilar-veruhlar/ adresinden alındı.

Bell, J. (2009). Sanatın Yeni Tarihi. U.C. Ünlü\&N. İleri\& R. Gürtuna.(Çev.). İstanbul: NTV Yayınları.

Bird, M. (2016). Sanatı Değiştiren 100 Fikir. D. Öztok.(Çev).London.

Campbell, J. (2003). Batı Mitolojisi-Tanrının Maskeleri. K. Emiroğlu.(Çev. ), Ankara: İmge Kitabevi.

Cömert, B. (1999).Mitoloji ve İkonografi. Ankara: Ayraç Yayınevi.

Çoruhlu, Y. (2011a). Erken Devir Türk Sanatı-İç Asya'da Türk Sanatının Doğuşu ve Gelişimi. İstanbul: Kabalcı Yayınevi.

Çoruhlu, Y. (2011b). Türk Mitolojisinin Anahatları. İstanbul : Kabalc1 Yayınevi.

Deveci, A. (2013). Türk Mitolojisinin Görsel Sanatlarımızdaki Yeri Nerede? Turkish Studies (turkishstudies.net),8(13),795-810, Ankara.

Ergüven, E. (2012). Mitoloji. N. Elhüseyni.(Çev.). İstanbul: NTV Yayınları.

Esin, E. (2004). Orta Asya'dan Osmanlyya Türk Sanatında İkonografik Metinler. İstanbul: Kabalc1.

İpşiroğlu, N. \& İpşiroğlu, M. (2017). Oluşum Süreci Iç̧inde Sanatın Tarihi. İstanbul: Hayalperest Yayınevi.

İskenderzade, L.A. (2010). Göktürk Dönemi İnsan Figürlü Taş Anıtlar. Selçuk Üniversitesi Sosyal Bilimler Enstitüsü Dergisi (dergisosyalbil,selcuk.edu.tr),(24),256-269. 
Jung, C.G. (2009). İnsan ve Sembolleri. A.N. Tansü, Y.E. \& Güvenç, B. (2015, Ekim). Eski Türk Babaoğlu.(Çev.). İstanbul: Okuyanus Yayınları.

Kramer, S. N. (2001). Sümer Mitolojisi. İstanbul: Kabalc1.

Kuban, D. (2014). Batıya Göçün Sanatsal Evreleri. İstanbul: Türk İş Bankası Yayınları.

Mccall, H. (2011). Mezopotamya Mitleri. B. Baykara. ( Çev.). Ankara: Phoenix Yayınları.

Mutlu, B. (1997). Mitoloji. Eczacıbaşı Sanat Ansiklopedisi,2.,1273-1276, İstanbul: Yem Yayınları.

Moscati, S. (1985). Mezopotamya Sanatını Tanıyalım. C. Çalıklar.(Çev.). İstanbul: İnkilap Kitapevi.

Necatigil, B. (2011). Mitologya Sözlüğü. İstanbul: Sel Yayıncılık.

Ögel, B. (2014).Türk Mitolojisi,I-II., TTK Yayınları. Mitolojisinde Hayvan Motifleri Üzerine Düşünceler. Türk Dünyası Araştırmalarl, (http://turan.org.tr/),(218), 203218.

Tokyürek, H. (2013,Bahar).Eski Uygurcada Hayvan Adları ve Bunların Kullanım Alanları. Tübar (www.tubar.com.tr),(XXXIII), ss.221-281.

Turani, A. (2012). Dünya Sanat Tarihi.İstanbul: Remzi Kitabevi

Yücel, G. (2016). Ars- Illkelden Moderne Sanatın Tasarımı. İstanbul: Profil Yayınları.

Resim Web Adresi: Erişim Tarihi: Turklerin tarihe biraktigiiz-balbal: 20.04 .2018 tarihinde http://www.serenti.org/turklerin-tarihe-biraktigi-izbalbal/ adresinden alındı.

Şenyapıl1, Ö. (2003). Otuz Bin Yıl Öncesinden Günümüze Heykel. Ankara: MetuPress. 